\title{
Curating History in the COVID19 Era: Philadelphia Epidemics and Nineteenth- Century American Women's Medical Education
}

Physician and educator Henry Hartshorne's manuscript medical school lecture notes serve as a remarkable record of the response by faculty and women students in Philadelphia to transitions from post-bellum education to scientific, laboratory-based curriculum. ${ }^{1}$ These archives document the tensions felt throughout the medical system due to extended classroom hours and competition for limited clinical rotation assignments experienced by those treating patients in urban Philadelphia during the 1870 s. $^{2}$ Hartshorne was not the only physician who trained female attendees at area institutions including Women's Medical College during this point of transition in both the education and practice of medicine. ${ }^{3}$ Yet his

1. On women physicians, medical education, and clinical practice during the late nineteenth century, see, for example, Mary Roth Walsh, "Doctors Wanted: No Women Need Apply": Sexual Barrier in the Medical Profession 1835-1975 (New Haven, CT: Yale University Press, 1977); Regina Markell Morantz and Sue Zschoch, "Professionalism, Feminism, and Gender Roles: A Comparative Study of Nineteenth Century Medical Therapeutics," Journal of American History 67 (1980): 569-88; Virginia G. Drachman, "Female Solidarity and Professional Success: The Dilemma of Women Doctors in Late Nineteenth-Century America," Journal of Social History 15, no. 4 (Summer 1982): 607-19; Regina Morantz-Sanchez, Sympathy and Science: Women Physicians in American Medicine (Chapel Hill, NC: University of North Carolina Press, 1985); Regina Morantz-Sanchez, "The 'Connecting Link': The Case for the Woman Doctor in 19thCentury America," in Sickness and Health in America: Readings in the History of Medicine and Public Health, eds. Judith Walzer Leavitt and Ronald L. Numbers, 3rd ed., revised (Madison, WI: University of Wisconsin Press, 1997), 213-24; Susan Wells, Out of the Dead House: Nineteenth-Century Women Physicians and the Writing of Medicine (Madison, WI: University of Wisconsin Press, 2001); Elizabeth Fee and Theodore M. Brown, "An Eventful Epoch in the History of Your Lives," American Journal of Public Health 94, no. 3 (Mar. 2004): 367. On women physicians and historiography, see Toby A. Appel, "Writing Women into Medical History in the 1930s," Bulletin of the History of Medicine 88, no. 3 (Fall 2014): 457-92.

2. On philosophical and practical implications of the various perspectives emphasized in medical school education in Philadelphia during the late nineteenth century, see, for example, Naomi Rogers, "The Proper Place of Homeopathy: Hahnemann Medical College and Hospital in an Age of Scientific Medicine," The Pennsylvania Magazine of History and Biography 108, no. 2 (Apr. 1984): 179-201; Anne Taylor Kirschmann, "Adding Women to the Ranks, 1860-1890: A New View with a Homeopathic Lens," Bulletin of the History of Medicine 73, no. 3 (Fall 1999): 429-46.

3. Steven Peitzman evaluated the impact of professors of medicine including Henry Hartshorne at Philadelphia’s Women's Medical College (WMC): Steven J. Peitzman, "Why Support a Women's Medical College? Philadelphia's Early Male Medical Pro-Feminists," Bulletin of the History of Medicine 77 (2003): 576-99. On the history of WMC more broadly, see Steven J. Peitzman, A New and Untried Course: Women's Medical College and Medical College of Pennsylvania, 1850-1998 (New Brunswick, NJ: Rutgers University Press, 2000).

(C) 2021 by Anne Ricculli (CC BY-NC [https://creativecommons.org/licenses/by-nc/4.0/]). 
annotated lecture materials, inserted newspaper clippings, and personal anecdotes present today's scholars with a palimpsest revealing shifts in the education of women physicians in family and pediatric medicine during successive waves of infectious disease epidemics. It is precisely because the Henry Hartshorne collection so clearly captures the participants' awareness of the rate of change within and among their institutions that these documents have additional value for educators, in particular those teaching distance curricula using Learning Activity Management Systems (LAMS). This article engages with the Henry Hartshorne papers, digitized and preserved in the archives of The College of Physicians of Philadelphia Historical Medical Library, as a case study in developing learning goals for history courses and seminars that aim to educate undergraduate students on the ways in which historians "work" with archives-both in the past and under current pandemic restrictions in the United States. ${ }^{4}$ These comparative perspectives empower students to explore the archives during independent research and to anticipate and articulate challenges faced when exploring the past using virtual environments. I examine Hartshorne documents relating to his tenure as professor at Women's Medical College in Philadelphia as an exercise in facilitating classroom discussions that evaluate how primary sources demonstrate contemporaries' views of change over time and explore applications for these texts to undergraduate education in historiography. Next, I address issues raised by students regarding the authenticity of digital primary source documents. Finally, I present a useful theoretical framework on silences, or gaps, in archives that I have used during class sessions to engage college freshmen in conversation about how history "works" in digital environments. Many of my students who select areas of academic study including science, public health, environmental history, communications, and early childhood education are born after the year 2000. While many are facile with digital technology, these students observe the ways in which the writing of history can be impacted in an all-digital environment. My goal for this article is to share ways to challenge students to articulate these differences in historical practices and critically assess silences, or gaps, in the archives used in their own research.

4. About the project: "For the Health of the New Nation: Philadelphia as the Center of American Medical Education, 1746-1868, funded by The Council on Library and Information Resources's (CLIR) Digitizing Hidden Special Collections and Archives program provides access to 140,000 pages of lecture tickets, course schedules, theses, dissertations, student notes, faculty lectures notes, commencement addresses, opening addresses, and matriculation records. These documents, curated from the repositories of six Philadelphia Area Consortium of Special Collections Libraries (PACSCL) members, share not only the voices of the medical greats, but also the often-unheard voices of students, providing the most comprehensive view of the history of medical education in Philadelphia." Online, https://archive.org/ details/fhnn?tab=about. The project is supported by the Council on Library and Information Resources (CLIR): https:/ / pacscl.org/for-the-health-of-the-new-nation-digitizing-140000-pages-of-early-medicaleducation-records/. 


\section{"The Value of a Good Working Theory"}

Scrawled in hurried handwriting at the top of his lecture notes, the medical school professor's written advice for those he called "my scholars" unequivocally emphasized emerging ideas about health and sanitation promoted by adherents of the

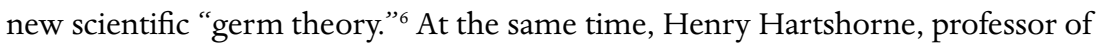
medicine at the Women's Medical College of Pennsylvania, understood all too well the challenges his charges would encounter when examining the pediatric population in urban Philadelphia during the late nineteenth century. Typhus, typhoid, smallpox, and waterborne illnesses including cholera impacted young and old. For Hartshorne, oral hygiene was a particular concern. The physical examination of the young patient's mouth offered critical clues for the physician on overall health, often disclosing conditions including diphtheria, scarlet fever, measles, and thrush. Inspection of the throat of young patients for early diagnostic signs, however, presented specific challenges. "For throat, more difficulty," the experienced clinician cautioned, suggesting his medical students use the "handle of dessert-spoon, or a moderate sized ivory paper-cutter (washed first)" in their clinical rotations. ${ }^{7}$ His admonition to sanitize household implements such as the spoon and paper-cutter, concurrent with conducting lectures and laboratory exercises in bacteriology and pharmacology, demonstrate the application of the 1870s germ theory by the city's medical school professors in both theory and practice. Hartshorne's advice exemplified his approach to clinical medicine and public health in a manner that combined both scientific and practical guidance.

Physician and educator Henry Hartshorne (1823-1897) addressed the University of Pennsylvania medical school faculty on the anniversary of the institution's inclusion of basic science instruction in physician education 60 years earlier. Hartshorne saw the merits in engaging with available "good working theory" in both the quotidian practice of medicine and to initiate short-term programs to improving public health, yet at the same time cautioned his audience on the risks associated with

5. Henry Hartshorne, "Introductory Lecture to the Tenth Course of Auxiliary Faculty of Medicine, University of Pennsylvania," (Mar. 22, 1875), 24 (emphasis original). Series IV: Lecture Courses, Subseries 4.4: University of Pennsylvania Auxiliary Faculty of Medicine of the Henry Hartshorne Papers (MSS 2 /030). Anna Hartshorne donated The Henry Hartshorne papers to the Historical Medical Library of the College of Physicians of Philadelphia in 1956.

6. Henry Hartshorne, "Temperaments," 6 in "Etiology [1]," Box: 6, Folder: 18-19. Series IV: Lecture Courses, Subseries 4.6: Woman's Medical College of Philadelphia of the Henry Hartshorne Papers (MSS 2/030). Hereafter HH MSS 2/030. https: / / archive.org/details/MSS-2-030_B06_S4.6_F3a.1/page/n21/ mode/1up. In his anniversary address at the University of Pennsylvania, for example, Hartshorne noted that "every physician should be, to use a new but very convenient word, a scientist." Hartshorne, "Introductory Lecture to the Tenth Course of Auxiliary Faculty of Medicine, University of Pennsylvania," 18. See also Thomas S. Huddle, "Competition and Reform at the Medical Department of the University of Pennsylvania, 1847-1877," Journal of the History of Medicine and Allied Sciences 51, no. 3 (July 1996): 251-92.

7. Henry Hartshorne, "Hygiene and Medical Management of Children [2], circa 1868-1876," 14. HH MSS 2/030. https://archive.org/details/MSS-2030_B06_S4.6_F4.2/page/n21/mode/2up 
complacency, accepting as "dogma" newly received information without seeking the critical skills necessary to advance medical science. ${ }^{8}$ The Hartshorne papers document the physician's efforts to convey to his students at Women's Medical College precisely these goals of responding to acute crises of infectious disease presenting in Philadelphia populations and, more broadly, to discern what counted as scientific and essential public health concerns as the medical school curriculum shifted to a laboratory-based education.

Hartshorne introduced his women students to the specific requirements demanded of those working with pediatric populations. His input was based on clinical observations of children, during encounters both routine and emergent. His notes document his records maintained and recorded over multiple sessions, as he annotated and amended text after reading updated information in journals and periodicals. As with many of his documents in this archival set, handwritten pages show layers of additions and edits, perhaps with the goal for didactic clarity, yet also recording changes in opinion, method, or practice. Hartshorne's lecture notes stressed that his students developed their own skills at critical observation. On what appears to be the reverse of the cover sheet titled "Medicines especially available for children," Hartshorne included the caveat "according to my experience." Of note are the consistent reference to pediatrics as a medical practice that required, above all, restraint. Dosing and therapeutic measures stressed the ways in which these patients differed from the adult population, with caveats for the administration of medicines including "small dose," "not disagreeable," "maximum," and "not too much."” Today's students reading these documents can trace the processes through which theory and practice converged in the emerging field of pediatric medicine.

Hartshorne's notes are a work in progress that incorporated publications on pediatric illness and diagnosis relevant to practitioners throughout Philadelphia. ${ }^{10}$ Hartshorne curated these varied sources in his lecture notes, using multiple annotations and crafting his own index for diseases of childhood specific to the urban patient population during the 1870 s and 1880 s. For example, Hartshorne's planned lecture for the Women's Medical College included public health statistics for the incidents of scarlet fever in the United States. He tabulated data for Philadelphians of all ages from 1809 through 1868 and included summary data representing more

8. Hartshorne, "Hygiene and Medical Management of Children." Hartshorne here articulated what Thomas Kuhn would later characterize as the working of "normal science" until participants are prodded through crisis to a paradigm shift. Thomas Kuhn, The Structure of Scientific Revolutions, 3rd ed. (Chicago, IL: University of Chicago Press, 1996).

9. Henry Hartshorne, "8th Lecture," 1. HH MSS 2/030. MSS-2-030_B06_S4.6_F4.2_0050 (emphasis original).

10. For example, the title "West's Principal Diseases of Childhood" corrected to read "(mainly after West-)." For today's students of public health, Hartshorne's notes offer a reading list of late nineteenth-century medical research. HH MSS 2/030. MSS-2-030_B06_S4.6_F4.2_0102. 
than 50,000 cases reported from London during the 18-year period from 1848 to 1866. ${ }^{11}$ Perhaps of particular interest for educators preparing materials for distance learning in the LAMS platform is Hartshorne's annotated version of his previously published 1866 pamphlet Cholera: Facts and Conclusions as to Its Nature, Prevention, and Treatment. ${ }^{12}$ The lecturer's compilation of newspaper clippings, journal articles, and his own statistics document the perspectives of an experienced clinician capturing the emergence of what was subsequently termed the "fourth wave" of pandemic cholera (1863-1875). ${ }^{13}$ The dates of the collected artifacts demonstrate Hartshorne's aims to update his lecture notes, integrating European statistical data, anecdotal findings, journalism, and research. Students accessing evidence of the professionalization of public health in the United States can document Philadelphians' awareness of the impending reemergence of pandemic cholera concurrent with the shift to a science-based medical education. ${ }^{14}$

The Hartshorne folders representing lecture notes for Women's Medical College on the topic of vaccines additionally complements educational learning goals for understanding historical context. The physician's papers document emerging issues in Philadelphia public health during the late nineteenth century. Hartshorne's title page, "Variola and Vaccinia," his lecture notes on revaccinations, and meticulously maintained statistical records demonstrate trans-Atlantic communication on evolving therapies. ${ }^{15}$ Yet public health education among American medical students, male and female, covered more than topics on infectious diseases. Hartshorne's examination questions in etiology suggest a broader range of themes that professors stressed in their lectures. Issues ranged from racial science and disability to the impact of climate on population health and incidence of yellow fever. Women's Medical College students were asked to evaluate the construction of conduits for Pennsylvania’s Schuykill River water supply. ${ }^{16}$ For undergraduate students study-

11. HH MSS 2/030. MSS-2-030_B06_S4.6_F4.2_0059.

12. Henry Hartshorne, Cholera: Facts and Conclusions as to Its Nature, Prevention, and Treatment (Philadelphia: Lippincott, 1866). Under “Etiology” Series IV: Lecture Courses, Subseries 4.6: Woman’s Medical College of Philadelphia of the Henry Hartshorne Papers (MSS 2/030).

13. The global spread of cholera coincided with pilgrimage to Mecca and, as Hartshorne noted, the opening in Egypt of the Suez Canal: Hartshorne, Cholera, 15. On cholera, see, for example, Charles Rosenberg, The Cholera Years (Chicago, IL: University of Chicago Press, 1987).

14. For further information on public health issues in Philadelphia during the decades surrounding the year 1900, see, for example, Gretchen A. Condran, Henry Williams, and Rose A. Cheney, "The Decline in Mortality in Philadelphia from 1870 to 1930: The Role of Municipal Services," The Pennsylvania Magazine of History and Biography 108, no. 2 (April 1984): 153-77.

15. On the use of Vaccinia virus (VACV) in smallpox vaccinations, see, for example, Bertram L. Jacobs, et al., "Vaccinia Virus Vaccines: Past, Present and Future," Antiviral Research 84, no. 1 (2009): 1-13.

16. Hartshorne's examination questions for WMC included the following: "What is meant by the 'Germ Theory of Disease'?" 11; "State and compare the different ways of disposal of sewage and conservancy," 19; "Which appear to have the greatest number of insane persons among them: civilized or barbarous nations? How is this explained?" 17; "Name an example of race acclimatization. Give a brief account of the geography of Yellow Fever," 14 (emphasis original). HH MSS 2/030. MSS-2-030_B06_ S4.6_F3b_0013. 
ing in the American Progressive Era social and cultural history, these documents substantiate current historical scholarship. More broadly, for scholars of medical school education in the United States, Hartshorne's inclusion of these topics demonstrates the professor's own assessment of topics critical for the education of medical students, further suggesting the trajectory of physician engagement with these themes in the final decades of the nineteenth century.

\section{"My Scholars”: Critical Reading Skills in a Digital Age ${ }^{17}$}

Professional archivists have long recognized the value of primary source documents for undergraduate history education in research and writing. ${ }^{18}$ Lesson plans use archives to introduce nonhistory majors to themes in the history of science. ${ }^{19}$ Educator Julie Harper Pace recently recognized the merits of collaborating with archivists to curate materials for students studying nineteenth-century epidemic infection diseases. ${ }^{20}$ Yet what is a student's perspective on archival research, in particular when in-person access is not available? In informal conversations, my students shared that they did think critically about historical methods in the digital environment. Their concerns centered on two main themes: navigating the volume of information available and document originality with issues of "trust" or authenticity. The manner in which Henry Hartshorne engaged with his students at Women's Medical College, the cohort he regarded as "my scholars," may serve as a template for educators seeking to engage today's students in contemporary research methods.

First, Hartshorne was a voracious reader and compiler of both published and anecdotal evidence. His medical students benefited from his curated lecture notes, which were frequently annotated and updated. Hartshorne's written notes are a palimpsest, with rampant insertions as well as deletions of outdated text. Today's students ask for guidelines on when to stop reading; in other words, they question how historians know when they are finished researching and can go on to begin writing. For this generation, the overwhelming volume of evidence available online presents issues of time management, and several spoke of searching for the "key" document that will connect or unify their research into a coherent whole. In a virtual classroom, the "breakout room" and discussion board platforms require stu-

17. Hartshorne, "Temperaments," 6.

18. Sammie Morris, Lawrence J. Mykytiuk, and Sharon A. Weiner, "Archival Literacy for History Students: Identifying Faculty Expectations of Archival Research Skills," American Archivist 77, no. 2 (Fall/ Winter 2014): 394-424; "Case Studies on Teaching with Primary Sources (TWPS)," eds. Kayla Harris and Blake Spitz, Society of American Archivists (March 1, 2021), https: / www2.archivists.org/publications/epubs/Case-Studies-Teaching-With-Primary-Sources.

19. Leigh Rupinski, "Bingo! Engaging History of Science Students with Primary Sources," no. 13 in "Case Studies on Teaching with Primary Sources (TWPS)," Society of American Archivists (April 2020), https://www2.archivists.org/sites/all/files/TWPSCase_13_Bingo-Engaging_History_of_Science_Students.pdf.

20. Julie Harper Pace, "Preserving the Archives in the 21st Century Classroom: Designing History Classes around Primary Source Research," Georgia Educational Researcher 16, no. 1 (2019): 63-73. 
dents to present concise summaries of their argument and evidence for peer review and feedback. Put simply, presenting research in the LAMS format gives students the opportunity to offer an argument-based summary of curated evidence.

Next, students asked if document originality mattered while conducting research. Conscious of the circulation of material facilitated through online platforms and the facility through which documents can be altered, they suggested that duplicate presentations of images diluted or minimized historical relevance. This is a key finding, which emphasizes that education is needed in the labor involved in constructing, maintaining, and accessing digital archives derived from physical materials. For scholars with a working knowledge of predigital research, scanned and uploaded documents represent a facsimile; originality is reserved for the resources maintained "on-site." In an era of restricted access and travel, students infer that the burden of proof for document originality rests with the onscreen viewer, not with the archive or museum website as content provider. Here, too, archive professionals can supplement previous emphasis on first-hand observation-Hartshorne's advice to clean the paper-cutter before inserting into the mouth of the next pediatric patient-with education designed to increase trust in document integrity. Finally, students were aware that they digitally access sets of documents "frozen in time," with items uploaded or absent (at the time of this writing) based on archival practice workflow. The LAMS platforms reinforce the idea of documents viewed in isolation. Conversations about archival document order and storage would clarify issues of authenticity.

\section{On Silence}

The value of teaching historiography, historical working methods, archival materials, and scholarly approaches to primary source document engaging in a variety of disciplines is more relevant now than ever. Students must be able to assess the extent to which historians' access to materials has changed and to evaluate impacts on a range of historical output, ranging from books and monographs to film documentaries, from textbooks to blog posts. How do historians evaluate online data, and what new frameworks are needed to negotiate the gaps in these digital archival records? To what extent will historical output from this period be different, and why does that question matter? "Silences," as anthropologist Michel-Rolph Trouillot has cautioned, "enter the process of historical production at four crucial moments."21 For Trouillot, exclusions and erasures from historical records may occur initially at the time of the event, but they also continue during document collection, through subsequent access to curated collections, and finally during interpretation.

21. Michel-Rolph Trouillot, Silencing the Past: Power and the Production of History, 2nd edition (Boston, MA: Beacon Press, 2015), 26. 
In "Exploring Ephemerality, Biases, and Silences in Archives," Lawrence University archivist and assistant professor Erin Dix explained her approach to "engaging novice undergraduates with notions of ephemerality, biases, and silences in archives." 22 Her syllabus design for the in-person course titled "Archival Discoveries" incorporated scholarly readings that prepared students for conversations on the impact of incomplete archives on historical narratives. ${ }^{23}$ I argue that the need for context on how archives are constructed, maintained, and accessed is more salient when access is restricted. I assigned selections from Trouillot's Silencing the Past: Power and the Production of History to my undergraduate students to draw their attention to the mechanics of archival access-specifically, in an on-line environment. Mathias Decuypere's recent article in Critical Studies in Education offers a useful perspective, arguing that interpreting the impact of Learning Activity Management System platforms requires an assessment of the digital environment in the context of networks. ${ }^{24}$ "A digital education platform," Decuypere notes, "is a coming-together of usage and movement, of force and value, of mediation and formation." ${ }^{25}$ The digital environment does not necessarily constrain pedagogy; rather, it challenges educators to think differently about opportunities for "the unfolding of 'other' educational possibilities." ${ }^{26}$ Put simply, evaluating undergraduates' engagement with digital archives requires assessing the extent to which students comprehend "why" certain documents are available in the first place. I suggest that the field of libraries and archives leverage this framework of opportunity as an avenue through which to educate students and demystify the process of collections formation and management.

My article has engaged with issues of "access" and challenges the notion that increased availability using digital archives, or what Trouillot regarded as the "moment of fact retrieval," is inherently subordinate to personal on-site investigations of specific documents or sets of collections. In "Curating History in the COVID19 Era: Philadelphia Epidemics and Nineteenth-Century American Women’s Medical Education," I have argued that the Learning Activity Management System template for collaborative engagement with primary source materials may provide a virtual space in which student curators can cancel "silences" with alternative perspectives, or Trouillot's "moment of retrospective significance." Issues raised in the conversation presented here, I assert, will continue to resonate as additional archives are digitized and made available to researchers.

22. Erin Dix, "Exploring Ephemerality, Biases, and Silences in Archives," no. 5 in "Case Studies on Teaching with Primary Sources (TWPS)," Society of American Archivists (April 2020), 1-7, https:/ /www2. archivists.org/sites/all/files/TWPSCase_5_Exploring_Ephemerality.pdf.

23. Dix assigned for course reading Rodney G.S. Carter, "Of Things Said and Unsaid: Power, Archival Silences, and Power in Silence," Archivaria 61 (Spring 2006): 215-33. Dix, "Exploring Ephemerality, Biases, and Silences in Archives," 4.

24. Mathias Decuypere, Emiliano Grimaldi, and Paolo Landri, "Introduction: Critical Studies of Digital Education Platforms," Critical Studies in Education 62, no. 1 (2021): 1-16, https: / doi.org/10.1080/17508487.2020.1866050.

25. Decuypere, Grimaldi, and Landri, "Introduction: Critical Studies of Digital Education Platforms," 8.

26. Decuypere, Grimaldi, and Landri, "Introduction: Critical Studies of Digital Education Platforms," 12. 